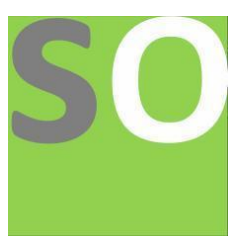

Article title: Students Mathematics Interest as Correlate of Achievement in Mathematics: Evidence from a Sub-Saharan Student Sample

Authors: Ngutor Tembe[1], Paul Igber Anyagh[2], Benjamin Ogbole Abakpa[3]

Affiliations: Department of Mathematics Education, Federal University of Agriculture Makurdi, Nigeria[1]

Orcid ids: 0000-0002-7962-3248[1]

Contact e-mail: ngutortembe@gmail.com

License information: This work has been published open access under Creative Commons Attribution License http://creativecommons.org/licenses/by/4.0/, which permits unrestricted use, distribution, and reproduction in any medium, provided the original work is properly cited. Conditions, terms of use and publishing policy can be found at https://www.scienceopen.com/.

Preprint statement: This article is a preprint and has not been peer-reviewed, under consideration and submitted to ScienceOpen Preprints for open peer review.

Funder: Self

DOI: 10.14293/S2199-1006.1.SOR-.PPLYPGG.v1

Preprint first posted online: 03 December 2020

Keywords: Student Interest, Mathematics Achievement. 


\title{
Students Mathematics Interest as correlate of achievement in Mathematics: Evidence from
}

\section{a sub-Saharan student sample}

Ngutor Tembe

Department of Mathematics Education, Federal University of Agriculture Makurdi, Nigeria.

Paul Igber Anyagh

Department of Mathematics Education, Federal University of Agriculture Makurdi, Nigeria.

Benjamin Ogbole Abakpa

Department of Mathematics Education, Federal University of Agriculture Makurdi, Nigeria.

\begin{abstract}
This study was carried out to investigate Mathematics interest as a correlate of Basic 9 students' achievement in Mathematics in Gboko Metropolis, Benue State, Nigeria. Three research questions were asked and three hypotheses were formulated. The study adopted a correlation design. The population of the study was 3,682 while a sample of 400 Basic 9 students was drawn from ten secondary schools using multistage sampling procedure made up of 200 male and 200 female students. Two research instruments Maths Interest Inventory (MII) and Students Mathematics Achievement Test (SMAT) were adapted. The instruments were validated by three experts and trial-tested, on a population outside the study area. Cronbach Alpha reliability coefficient was used to get the reliability coefficient of MII which was 0.83 . While that of SMAT was 0.65 using Kuder-Richardson 21 formula. The research questions were answered using Pearson Product Moment Coefficients and hypotheses were tested at 0.05 level of significance using p-values of Pearson Product Moment Coefficient. The findings of the study revealed that there was a significant relationship between Mathematics Interest and students' achievement in Mathematics. Furthermore, there was a significant relationship between Mathematics Interest and students' achievement in Mathematics among male and female students. The study recommends that Interest have the potential of improving students' achievement positively and should be encouraged among students.
\end{abstract}

Keywords: Student Interest, Mathematics Achievement.

\section{Introduction}

In Nigeria, Mathematics is a compulsory subject in primary and secondary school. It is also expected that a student should obtain at least a credit pass in WAEC or NECO as a basic requirement to gain admission into the University. However, the achievement of students has 
continuously being a challenge. In the just released WAEC result of May/June 2020, out of the 316,999 students who registered for the examination across the country, only $38.33 \%$ of the students obtained at least a credit pass (Waec chief examiner's report, 2020). This is worrisome and calls for relentless efforts in research to see to it that achievement of students in Mathematics is improved upon.

Academic achievement is commonly measured through examinations or continuous_assessments but there is no general agreement on how it is best evaluated or which aspects are most important. Furthermore, there are inconclusive results over which individual factors successfully predict academic performance; elements such as test anxiety, environment, motivation, emotions, interest and self-concept among others require consideration when developing models of school achievement.

Mathematics achievement is an essential part of the academic achievement in the modern era. It is the key to success in many professions. Mangal (2008) opined that "An achievement test is essentially a tool or device of measurement that helps in ascertaining the quantity and quality of learning attained in a subject of study or group of subject after a period of instruction by measuring the present ability of the individual concerned."

Mathematical achievement is the competency shown by the student in Mathematics. It is the result of acquired knowledge or information, understanding, skills and techniques developed in the subject of Mathematics in a particular stage. Its measure is the score on the achievement test in Mathematics. Abakpa (2011) defines achievement as a measure of accomplishment in a specific field of study. He is of the opinion that demonstration of students' abilities to attain certain levels of instructional objectives outcome of their classroom instruction and experience is 
achievement. Students' achievement in Mathematics has always been a matter of concern to educational stakeholders because whatever students' achievement is will have an impact on the students themselves and the nation at large. This could explain the reason why there is so much campaign on the improvement of students' achievement in Mathematics by examination bodies such as WAEC, NECO and others.

Students' achievement could either be low or high, it is low when the students do not attain up to the desired expectation or bench mark of the instructor, and it is high when the performance of the learner is exactly or above the desired outcome of the instructor. So many factors could be said to account for low or high achievement in Mathematics. Some of these factors include teacher factors, school factors, parent factors and government factors (Akinoso, 2011). This implies that if students' achievement in Mathematics will be improved upon there must be a continuous investigation of various factors so as to ascertain new and innovative ways of learning and teaching Mathematics. That is why this study seeks to investigate Mathematics interest as a correlate of Basic 9 students' achievement in Mathematics.

Interest as a variable has assumed a plethora of meaning as there are authors to define it. Interest refers to a passion an individual may have towards a particular object. Silvia (2005) characterized interest as an emotion and using the cognitive appraisal theory explained the occurrence of interest in specific situations. The author also referred to interests as traits of people that are developed and sustained for a long period of time almost reaching the status of personality characteristics. However, it is important to state that interest may have distinctions which are noteworthy. The most important distinction in the numerous conceptualizations of interest concerns the time frame with which interest is being examined (Jansen, Lüdtke \& Schroeders 2016). 
A situation can raise interest in people that may only hold up for minutes or even seconds (interest-as-state). On the other hand, people may spend decades passionately pursuing an interest (interest-as-trait). Therefore, one important distinction introduced by Silvia (2001) was between "interest" and "interests. While interests are referred to as traits of people that are developed and sustained for long periods of time almost reaching the status of personality characteristics, an interest is characterised as an emotion. Also, Hidi and Renninger (2006) proposed an almost similar differentiation between short-term/situational and longterm/individual interests, and also described the process of developing dispositional individual interests from persisting situational interests. For the purpose of this study, interest is conceptualized as a characteristic of a relation between a student and a domain (Krapp 2002).

A student with high individual interest would be characterized by a consistently high cognitive commitment and emotional attachment to a specific (scholastic) domain. In that sense, interest is considered as domain-specific, cognitive and an affective component, that is built and nourished over the school career, and is assumed to be relatively stable over a variety of situations and over time. Mathematics interest is a complex behavioural aspect of Mathematics. It has so many characteristics and it can be attributed to as many situations as we discuss in Mathematics education. The key strategy of Mathematics teaching should focus on keeping the students interest on Mathematics. If the students are interested in learning Mathematics that should be helpful to their academic achievement and also teacher tasks become easier. Therefore, interest is a very important factor to consider in the teaching and learning process.

In a study, Unodiaku in Anigbo (2016) associated factors of academic achievement among secondary school students in Mathematics to lack of interest. Also, in a study on interest in 
Mathematics and Academic achievement Mohamed and Charles (2017) found that there is a significant difference in interest and academic achievement of secondary school students in respect of the type of management. More so, the failure of students in Mathematics achievement was also supported by some researchers to be associated with lack of interest in studying the subject, (Idigo, 2010; Goolsby, 2013). Specifically, Goolsby (2013) attributed factors influencing students' Mathematics interest to attitude towards success in Mathematics, confidence in learning Mathematics, perception of teacher attitude, Mathematics anxiety, and Locus of control. According to Idigo in Anigbo, factors associated with Mathematics interest include, students' factor, teachers factor, Mathematics anxiety, government, lack of infrastructural facilities, lack of instructional materials and problem of large class size among several other factors. Therefore, researchers have continued to investigate various factors that could influence the achievement of students in Mathematics.

Despite comparable achievement by females and males in a variety of Mathematics topics such as algebra, geometry and similar abilities associated with completing Math-related tasks, female interest in Mathematics is markedly lower than male interest (Frenzel, Goetz, Pekrun, \& Watt, 2010; Else-Quest, Hyde, \& Linn, 2010). At a young age girls and boys express similar interest in and positive attitudes toward math (Linver, Davis-Kean, \& Eccles, 2002); however, gender differences in Mathematics interest become apparent after elementary school. By Basic 9, boys are more likely than girls to indicate an interest in Mathematics (Linver et al., 2002). According to Freeman, (2004) lack of interest by girls is masked by course-taking patterns: Girls enrol in Mathematics-based courses throughout middle and high school at the same rate as boys do and perform as well on math-based standardized performance tests. These trends present a confusing picture of females and Mathematics. 
Therefore, research has focused on identifying experiences that might explain the lack of interest among females despite the fact that they and males demonstrate equal aptitude for Mathematics (Spelke, 2005). One of the primary goals of college education is to help students discover their interests and chart a life course based on interests developed and nurtured in college. To that end, this study seeks to investigate to what extent interest relates with male and female students Mathematics achievement in Junior Secondary School.

Research Questions;

1. How does Interest relate with Basic 9 students' achievement in Mathematics?

2. How does Interest relate with Basic 9 male students' achievement in Mathematics?

3. How does Interest relate with Basic 9 female students' achievement in Mathematics?

Statement of hypotheses;

1. There is no significant relationship between Basic 9 students' Interest and achievement in Mathematics.

2. There is no significant relationship between Basic 9 male students' Interest and their achievement in Mathematics.

3. There is no significant relationship between Basic 9 female students' Interest and their achievement in Mathematics.

\section{Methodology}

\section{Research Design}

The study adopted a correlational design. This type of design seeks to establish the relationship that exists between two or more variables. Hence, it was employed because the researcher was 
seeking to establish the relationship between the one independent variable (Interest) and one dependent variable (students' achievement).

\section{Procedure}

The instruments were administered by the researcher alongside two research assistants. The respondents were adequately informed of the purpose of the research and the need to respond objectively. The Maths Interest inventory was first administered, which lasted for 10minutes.

After retrieving the first, the SMAT was then administered and retrieved after the expiration of 1hour. The respondents' responses in the two instruments were scored and collated for analysis. The maximum score for SMAT was 40 and each correct item attracted 1 mark and incorrect option attracted zero (0), while the maximum rating scores for MII was 4 .

\section{Instruments for Data Collection}

Two instruments were used for data collection. The first was a 20-item interest inventory developed by Snow in (2011) titled, "Math interest inventory" (MII) was adapted, in which the students were asked to rate how they think, feel, act, value and evaluate themselves in Mathematics on a four-point scale, namely: Strongly Agree=4, Agree=3, Disagree $=2$ and Strongly Disagree=1. The researcher adapted MII to measure specific interest content in Mathematics as well as taking cognisance of the research topic and respondents involved in the study.

The second instrument was a 40-item multiple choice Students' Mathematics Achievement Test (SMAT) adapted from the Basic Education Certificate Examination (BECE) past questions. SMAT was adapted because the items on the BECE were too many and had cut across the entire upper Basic Mathematics curriculum which not all schools which the researcher sampled may have covered. The SMAT consisted of two sections, section A contains the information on the 
respondents that is class, time allowed and sex, while section B contains the questions The total mark obtainable from SMAT is 40 marks. The reliability of the two instruments was found to be 0.83 and 0.65 respectively.

\section{Data Analysis}

The Pearson Product Moment Correlation Coefficient was used to answer the research questions, while the significant values of Pearson Product Moment Correlation Coefficient were used to test the hypotheses at 0.05 level of significance. A positive Correlation Coefficient implied a positive self-concept.

\section{Results}

The section deals with the results according to the research questions and hypotheses . To ascertain the relationship between Mathematics interest and Basic 9 students achievement in Mathematics.

Table 1: Correlation of Basic 9 Students Mathematics Interest and Achievement in Mathematics.

\begin{tabular}{lcc}
\hline Variable & Number of Students & Pearson Correlation (r) \\
\hline Interest & 400 & .298 \\
& & \\
Achievement & & \\
\hline
\end{tabular}

It was seen from table 1 that the correlation between students Mathematics interest and their achievement is 0.298 , which indicated a weak positive relationship between Mathematics interest and students' achievement in Mathematics. This implied that as students' Mathematics interest increases their achievement in Mathematics also increases. 
To find out relationship between Basic 9 students Mathematics interest and their achievement in Mathematics, the bivariate correlation has been used and tested at 0.05 level of significance.

$\mathrm{H}_{0}$ : There is no significant relationship between Basic 9 students' interest and achievement in Mathematics.

Table 2: Show the Correlation between Students Mathematics Interest and Students' Achievement in Mathematics.

\begin{tabular}{lccc}
\hline Variable & Number of Students & Pearson Correlation (r) & Sig. \\
\hline Interest & 400 & .298 & \\
& & & .000 \\
Achievement & & & \\
\hline
\end{tabular}

In Table 2, the result shows that the sig-value of 0.000 is less than the alpha value of 0.05 level of significance. This shows that the test is significant. Therefore, the null hypothesis of no significant relationship is rejected. The result implies that there is a significant relationship between Mathematics interest and students' achievement in Mathematics.

To find out correlation between Basic 9 students Mathematics interest and their achievement in Mathematics among male and female, the bivariate correlation has been used and tested at 0.05 level of significance.

$\mathrm{H}_{0}$ : There is no significant relationship between Basic 9 Male students' interest and achievement in Mathematics.

$\mathrm{H}_{0}$ : There is no significant relationship between Basic 9 Female students' interest and achievement in Mathematics. 
Table 3: Show the Correlation of Basic 9 Male and Female Students' Mathematics Interest and their Achievement in Mathematics.

\begin{tabular}{lccc}
\hline Students & Number of Students & Pearson Correlation (r) & Sig. \\
\hline Male & 200 & .647 & 0.000 \\
& & & \\
Female & 200 & .168 & 0.017 \\
\hline
\end{tabular}

Male $=\mathrm{P}<0.05$, Female $=\mathrm{P}<0.05$.

It was seen in Table 3, that male students had a correlation coefficient of 0.647 while the female students had 0.168 which indicates that both male and female students Mathematics interest has a positive relationship with Mathematics achievement. However, that of the males students indicated a stronger relationship than the females.

The result also shows that the sig-value of Male students is 0.000 which is less than the 0.05 level of significance and that of the female students is 0.017 which is less than 0.05 level of significance. This shows that the test is significant. The result implies that there is a significant relationship between the Mathematics interest of students and Mathematics achievement among male and female students. Therefore, the null hypothesis of no significant relationship is not accepted.

\section{Discussions}

The result in this study shows that students Mathematics interest has a positive relationship with students' achievement in Mathematics.The findings of this study agrees with the findings of Omototade, et al (2016) confirming that there is a significant relationship between students' interest and students' academic performance. Likewise, these findings corroborate with that of 
Essien, et al (2015) which further confirms that there is a significant relationship between students' interest and achievement. The findings of this study also, agrees with that of Mohamed and Charles, (2017) who reported that there was a significant difference in interest and academic achievement of secondary school students. Also, Unodiaku in Anigbo (2016) attributed factors of academic achievement among secondary school students to be lack of interest. Furthermore, some authors like Idigo, (2010) and Goolsby, (2013) supported that the failure in Mathematics achievement was associated with lack of interest in studying the subject.

The result of this study showed that both male and female students have a positive relationship between Mathematics interest and achievement in Mathematics, although the males indicated a stronger relationship than females. The finding in this study corroborates with that of Else-Quest, et al (2010) and Frenzel, et al (2010) who remarked that female interest in Mathematics is markedly lower than Male students' interest.

\section{Recommendations}

The following recommendations are made based on the findings of this study.

1. State Ministries of Education through State Secondary School Education Boards is encouraged to promote the campaign of the need to improve the interest of students by organising conferences, seminars and workshops for serving teachers to educate them on the place of interest in the achievement of students in Mathematics in secondary schools. 
2. Mathematics Teachers should pay deliberate attention in the classroom making sure they build and boost the interest of their students as well as develop their interest in learning Mathematics.

3. Curriculum Planners should include contents that promote self-concept and Mathematics interest in Mathematics curriculum.

4. Textbook authors should include contents that spur and promote interest in Mathematics curriculum.

5. School Administrators should ensure Mathematics teachers present their lessons in such a manner that will encourage students interest in learning the subject.

6. Parents, should look for practical ways to encourage and develop interest among female students.

\section{Conclusion}

Based on the findings of this study, it is concluded that interest of students has the potential to influence the Mathematics achievement of students. This implies that the poor achievement of students in Mathematics can be improved upon if Mathematics teachers do not only concentrate on teaching methods, instructional materials etc. as ways of improving students' achievement but take cognisance of the interest of their students in learning Mathematics as a factor that may improve the poor performance of students in Mathematics. And, that the Mathematics interest of students have the potential of influencing the achievement of students in Mathematics with variations in gender. Therefore, the emphasis on the self-concept of students as it relates to their Mathematics achievement should be taken into cognisance. 


\section{References}

Abakpa, B.O. (2011). Effects of Mastering Learning Approach on Senior Secondary

School Students Achievement in Geometry. Unpublished Ph.D Thesis, Science Education Department, University of Agriculture, Makurdi.

Akinoso, S.O. (2011) Correlates of some factors affecting students' achievement in secondary school mathematics in Osun State. In International journal of education, science, mathematics and environmental studies (1 JESMES), University of Abuja 3(10): 8395.

Anigbo, L.C. (2016). Factors affecting Students' interest in mathematics in secondary schools in Enugu State. International Journal of Education and Evaluation. 2(1), 22-28.

Else-Quest, N. M., Hyde, J. S., \& Linn, M. C. (2010). Cross-national patterns of gender differences in mathematics: A meta-a analysis. Psychological Bulletin, 136(1): 103-127.

Essien, E. E., Akpan, O.E. \& Obot, I. M. (2015). Students' interest in social studies and academic achievement in Tertiary institutions. European Journal of Training and Development studies 2(2), pp. 35-40.

Freeman, C. E. (2004). Trends in educational equity of girls \& women: 2004 (NCES 2005- 016). Washington, DC: Government Printing Office.

Frenzel, A. C., Goetz, T., Pekrun, R., \& Watt, H. M. G. (2010). Development of mathematics interest in adolescence: Influences of gender, family, and school context. Journal of Research onAdolescence, 20(2), 507-537.

Goolsby, L. (2013). School Interest. Boston: Allyn and Bacon.

Hidi, S., \& Renninger, K. A. (2006). The four-phase model of interest development. Educational Psychologist, 41, 111-127.doi:10.1207/s15326985ep4102_4

Idigo, E.C. (2010). Effective method of Retaining Students Interest in Mathematics in Secondary Schools in Enugu East local Government area of Enugu State, Unpublished UG Thesis, Institute of Ecumenical Education, Thinker's Corner, Enugu, in Affiliation with (ESUT), Enugu.

Jansen, M., Lüdtke, O. \& Schroeders, U. (2016). Evidence for a positive relation between interest and achievement: Examining between-person and within-person variation in fivedomains,ContemporaryEducationalPsychology(2016),doi:http://dx.doi.org/10.1016/j. cedpsych.2016.05.004

Krapp, A. (2002). Structural and dynamic aspects of interest development: Theoretical considerations from an ontogenetic perspective. Learning and Instruction, 12, 383-409. doi:10.1016/S0959-4752(01)00011-1 
Linver, M. R., Davis-Kean, P. E., \& Eccles, J. S. (2002). Influences of gender on academic achievement. Retrieved from http://www.rcgd.isr.umich.edu/it/New/sra02fulpaper.doc

Mangal, S.K. (2008): Educational Psychology, New Delhi : Prentice Hall of India Pvt Ltd., Eds.2008, pp. 393398.5

Mohamed, I. B, \& Charles, M. A. (2017). Interest in Mathematics and academic achievement of high school students in Chennai district. International Journal of innovative science and research Technology. 2(8), 261-265.

Omototade, A. A, Funke, A. R, \& Oyewumi, F.-A. K.(2016) Students Attitude and Interest as correlates of Students Academic Performance in Biology in Senior Secondary School. International journal for innovation Education and Research,4(3) Retrieved from https://ijier.net/index.php/ijier/article/view/524.

Silvia, P. J. (2001). Interest and interests: The psychology of constructive capriciousness. Review of General Psychology, 5, 270-290. doi: 10.1111/cdev.12036

Silvia, P. J. (2005). What is interesting? Exploring the appraisal structure of interest. Emotion, 5, 89-102. doi:10.1037/1528-3542.5.1.89

Spelke, E. S. (2005). Sex differences in intrinsic aptitude for mathematics and science? A critical review. American Psychologist, 60(9), 950-958.

Snow, G. M. (2011). "development of a math interest inventory to identify gifted students from underrepresented and diverse population". Masters thesis \& specialist project. Paper 1052. http://digitalcommons.wku.edu/thesis/1052 